Test Flaming and Analysis TII-336

October 24,1962

Trangmittal of Docurwent

\title{
ATPOWUCLEAR LABORATORY
}

TO: Mr. H. Faught

Flesse sent two coples of the Irelintary Analysis of the

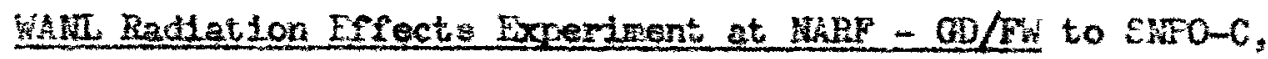

Attention: J. Lombario, end three copiea to AGC, Attention:

J. Thlipson, h. He veen.

5. 5. Steln, Hanager

Tezt Planning and knaiys is

/ratas

Enclosures

This report was price

sponsored by the prepared as an account of work

the United States Government Neither

Research and Development United States Energy

therr employees,

subcontractors, nor any of their contractors,

warranty, exs, or their employees, makes any

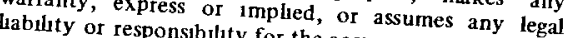

or usefulness of anylity for the accuracy, completeness

process dus of any information, apparatus, product

pingesents that its use would or

infringe privately owned rights 


\section{DISCLAIMER}

This report was prepared as an account of work sponsored by an agency of the United States Government. Neither the United States Government nor any agency Thereof, nor any of their employees, makes any warranty, express or implied, or assumes any legal liability or responsibility for the accuracy, completeness, or usefulness of any information, apparatus, product, or process disclosed, or represents that its use would not infringe privately owned rights. Reference herein to any specific commercial product, process, or service by trade name, trademark, manufacturer, or otherwise does not necessarily constitute or imply its endorsement, recommendation, or favoring by the United States Government or any agency thereof. The views and opinions of authors expressed herein do not necessarily state or reflect those of the United States Government or any agency thereof. 


\section{DISCLAIMER}

Portions of this document may be illegible in electronic image products. Images are produced from the best available original document. 
Preliminary Analysis of WANL Radiation Effects Experiment at NARF-GD/FW

(Aerojet Subcontract NP-5 Appendix C)

Attached is a preliminary analysis of the WANL radiation effects experiment that was performed in the "West Box" with the GTR on 9-29-62 to $10-2-62$.

1. Total reactor time* (north reflector $57 \mathrm{hr} 43 \mathrm{~min}$ $\leq$ 6")

2. Total MWH

3. Calculated integrated flux on box ( $E>0.1 \mathrm{Mev}$ )

4. Gamma dose
$273.5 \mathrm{MWHr}$

$6.6 \times 10^{16} \mathrm{n} / \mathrm{cm}^{2}$

$4.6 \times 10^{10}$

ergs/gm(C)

All the data and results herein are subject to change pending a more detailed analysis of the experiment.

*The GTR was withdrawn from its normal operating position several times because of fires in the irradiation space. Reflector thickness was then up to 100 inches of water. Effective experiment irradiation occurs when the reactor is less than 6 inches from the north face.

Test Planning and Analysis

J. B. Mc Guffin - WANL Site Representative

P. Blau - WANL Control Development

T. P. Murray - WANL Control Development 
Preliminasy Dalluse Duta for

WAII Radiation Esfecto Test

NARS - COL $/$ STi

\begin{tabular}{|c|c|c|c|}
\hline Congonenit & $\begin{array}{l}\text { Faijure } \\
\text { Tine-binn }\end{array}$ & 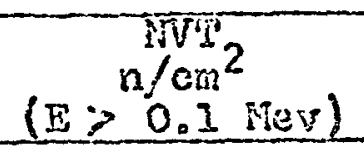 & Remaniss \\
\hline
\end{tabular}

I. Pressuie Transducers

A. DC Group
(1) $\mathrm{CrC}$ ?
(2) $\operatorname{CEC} 3$
(3) Stithan

$\begin{array}{ll}926 \rightarrow 1064 & 1.75 \rightarrow 2.01 \times 10^{16} \\ 926 \rightarrow 1064 & 1.75 \rightarrow 2.01 \times 10^{16} \\ 878 \rightarrow 1090 & 1.66 \rightarrow 2.06 \times 10^{16} \\ (B a d \text { zero } & \\ \text { shift) } & \end{array}$

(4) colvin

B. AC Group

(1) IRC I

(2) IRC 2

Did not $6.6 \times 10^{26}$.

Ersatic readings at'iost min;deflnito failure at $1317 \mathrm{~min}$.

Sande as CEC 2.

Fimats reacings at 1090 min. Zero shist to the rest of the test. Stuthan continued to read out in this pashion unttl the end of test. This ras not a positive raliure.

Slight change as a result of immession in $\mathrm{SN}_{2}$ prior to isradiation. At 562 mino resistance increased. This value was the same throughout toss. On post-imiaciation data cycie $\left(50^{\circ}\right.$ F) the resistance decreased to Its original value. $\therefore$

Failed during first Idr 2 cycle pxior to irradiation, lowever, pre-irradiation anbient and post-1rrediation ambient are approximately same.

Dafinite effect Irom $\mathrm{LN}_{2}$ submersion prion. to irradiation. This zeno shifi efrect and reduced output held sama throurhout test. Pre-1rradiation and post-irraciation amilent approximately the same. 
(3) Hancko 3

Did not Peis

(4) Wianclro 4
$6.6 \times 10^{16}$
No apparent combined efrects throughout test.

Definite $\mathrm{IN}_{2}$ erfect in sirst $\mathrm{IN}_{2}$ subrnersion. The change aue to IN was maintained without apparent change throughout the radiation test. The arbien'c and post-ambient yalues were the same. 


\section{Strain Gages}

Resistance of Gages

Of 12 gages whose resistance could be checked, 10 sho:sed changes of about $0.4 \%$, or, withsn the accuracy of the measurements, no change. Two gages showed increases of about $4 f$, in resistance. Insuration Resistance

Insulacion resistance to ground on the 7 bridges sho ied decreases Irom the orifinal values of the oinder of 1000 megohms to values as Iow as 7000 onms. Individual ridge values of insulation resistance at a given time duming tise sest ranged froin 7000 ohms to 5 megonms.

\section{Strain Measurement}

Tro of the bridges measuring strain chroughout the fost nathtalned ihair original values of Etrajin indication within about $10 \%$. One briage showed a loss of sensicivity of about $60 \%$.

Signals from the gages measuring strain could be obtained onity intermittently, due to malfunctioning of the strain actuating sJstem. This malfunctioning was due ejther to the actuating belio:10 becoming miseligred or due to formation of ice inside the bellowis, or a combination of both factors.

Remarics

It is not possible at present to separate cryogenic and radiation effects. 


\section{Reslstance Femperature Datectors}

The RID's were subritted by nerojet-Genoral for combined effects testing with the WhII transdueers.

The RTDis showed no apparent change fiom a preliusinary anelysis of the recorded data. . 


\section{Bearing Test}

Cychlng of the bearing tester thachinout tho expartment tas

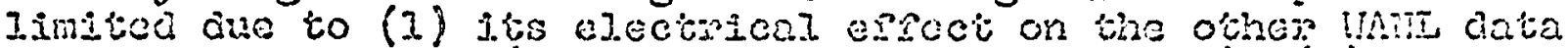

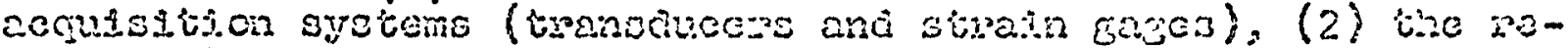

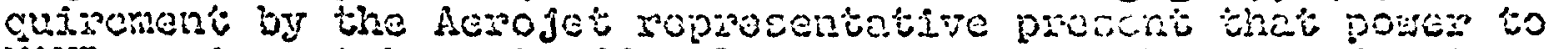
WANI eguiprent be cut off a larise anowit of tine thine due to pos-

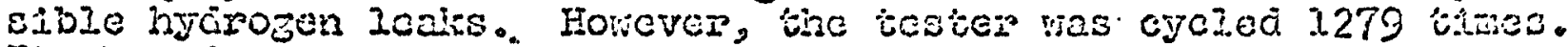
It showed no apparont fajlure at anyine throughous the firodiation.

Table II

Eearing Tester

\begin{tabular}{|c|c|c|c|}
\hline SW POS & $\begin{array}{l}\text { Reacoto } \\
\text { ranc-yin }\end{array}$ & Counts & Date \\
\hline $\mathrm{O}_{2}$ & 0 & 332 & $9-29-6$ \\
\hline
\end{tabular}

Eanting tester actuated latemitosuty duxing this time due to power off recuirements.

\begin{tabular}{|c|c|c|c|}
\hline 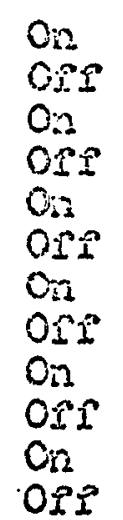 & $\begin{array}{l}2207 \\
2336 \\
2255 \\
2340 \\
2347 \\
2515 \\
2542 \\
2803 \\
2815 \\
3012 \\
3054 \\
3463\end{array}$ & $\begin{array}{l}165 \\
399 \\
399 \\
254 \\
286 \\
452 \\
452 \\
662 \\
662 \\
889 \\
889 \\
1411\end{array}$ & $\begin{array}{l}10-1-62 \\
10-1-62 \\
30-1-62 \\
30-1-62 \\
10-1-62 \\
10-1-62 \\
20-1-62 \\
10-1 \\
10-62 \\
10-2-62 \\
10--2-62 \\
10-2-62\end{array}$ \\
\hline
\end{tabular}




\section{Mietalize Tost Specinens}

Pulling of these specimens has not been accompished at this writing. 